\title{
A cellular model of oxidant-mediated neuronal injury
}

\author{
Daniel B. Hinshaw ${ }^{\text {a }}$, Mary T. Miller ${ }^{\text {a }}$, Geneva M. Omann ${ }^{\text {a,b }}$, Theodore F. Beals ${ }^{\text {c }}$ \\ and Paul A. Hyslop ${ }^{\text {d }}$ \\ Departments of ${ }^{a}$ Surgery, ${ }^{b}$ Biological Chemistry and ${ }^{c}$ Pathology, VAMC and the University of Michigan, Ann Arbor, MI (USA) and \\ ${ }^{d}$ the CNS division, Lilly Research Laboratories, Indianapolis, IN (USA)
}

(Accepted 19 January 1993)

Key words: PC 12 cell; Cell injury; Hydrogen peroxide; Microtubule; Microfilament; Cell calcium

\begin{abstract}
Oxidants derived from the partial reduction of oxygen are thought to play a significant role in neuronal injury. We present here a cellular model of neuronal injury mediated by hydrogen peroxide $\left(\mathrm{H}_{2} \mathrm{O}_{2}\right)$ using the PC 12 rat pheochromocytoma cell line. The organization of microtubules and microfilaments within neurites of $\mathrm{PC} 12$ cells differentiated by exposure to nerve growth factor was examined after $\mathrm{H}_{2} \mathrm{O}_{2}$ injury using fluorescence microscopy. Concentrations of $\mathrm{H}_{2} \mathrm{O}_{2}$ as low as $100 \mu \mathrm{M}$ produced an initial periodic pattern of microtubule depolymerization over 3-4 h which later progressed to complete depolymerization. Neuritic microspikes containing actin filaments were relatively more resistant to injury by $\mathrm{H}_{2} \mathrm{O}_{2}$ than microtubules. Blebbing of PC 12 cell bodies and neurites also was seen after $\mathrm{H}_{2} \mathrm{O}_{2}$ injury and the blebs appeared to contain microtubules. The destructive changes affecting neuritic structure preceded but were not essential for PC 12 cell lysis. Exposure of the cells to the $\mathrm{Ca}^{2+}$ ionophore, ionomycin $(25 \mu \mathrm{M})$ also produced the same pattern of microtubule depolymerization in PC 12 neurites as was seen after $\mathrm{H}_{2} \mathrm{O}_{2}$ injury suggesting that $\mathrm{H}_{2} \mathrm{O}_{2}$ may mediate its destructive effect on the neurites via elevation of intracellular $\mathrm{Ca}^{2+}$.
\end{abstract}

\section{INTRODUCTION}

Oxidants have been implicated in a variety of injuries to the central nervous system (CNS) including trauma and ischemia-reperfusion ${ }^{2,6,8,11,19}$. The generation of superoxide anion $\left(\mathrm{O}_{2}^{-}\right)$during the reperfusion of ischemic brain has been demonstrated in cats by measuring the reduction of nitroblue tetrazolium ${ }^{31}$. Similarly, using the same technique, $\mathrm{O}_{2}^{-}$production has also been demonstrated after fluid-percussion injury to the brain ${ }^{20}$. After the initiation of fluid-percussion injury to the CNS, progressive axonal damage has been noted, including degeneration, swelling and incomplete regeneration ${ }^{28}$. The mechanism responsible for the morphologic changes affecting neurites of the injured neurons is unknown.

A number of pathologic events affecting cellular morphology and the cytoskeleton have been demonstrated after oxidant exposure in non-neuronal cell types $^{9-11,13,17,23-25}$. Exposure of hepatocytes to $t$-butylhydroperoxide leads to the $\mathrm{Ca}^{2+}$-dependent formation of plasma membrane blebs ${ }^{14}$. Additional work has demonstrated that oxidants can induce oxidation of sulfhydryl groups in the microfilament protein ac$\operatorname{tin}^{13,23-25}$, initiate actin assembly ${ }^{11,13}$, and cause an ATP-dependent disruption of visible microfilament organization?. At concentrations of $\mathrm{H}_{2} \mathrm{O}_{2}$ which cause elevation of intracellular $\mathrm{Ca}^{2+}\left(\left[\mathrm{Ca}^{2+}\right]_{\mathrm{i}}\right)$, microtubule depolymerization has also been seen in injured endothelial cells ${ }^{10}$.

To better define the effect of oxidant injury on the structure of neurites and the relationship of such pathologic changes to neuronal cytotoxicity, we have developed a model of oxidant-mediated neuronal injury using the PC 12 pheochromocytoma cell line which develops a neuronal phenotype after 5-7 days exposure to nerve growth factor (NGF) ${ }^{5}$. The advantages of this cellular model include the ability to perform studies of neuronal injury with a single cell type, and for studies of cytoskeletal pathology many features of the cytoskeleton in these cells have already been characterized (e.g. ref. 3 and 26). In this study we demonstrate that PC 12 cells differentiated to a neuronal phenotype by NGF are quite sensitive to injury by $\mathrm{H}_{2} \mathrm{O}_{2}$. Concen- 
trations of $\mathrm{H}_{2} \mathrm{O}_{2}$ as low as $100 \mu \mathrm{M}$ induce a characteristic pattern of tubulin depolymerization in PC 12 neurites which is accompanied by blebbing along affected neurites and cell bodies of the injured cells, and these cytoskeletal and morphologic changes precede cell lysis. In contrast, actin filaments within neuritic microspikes are relatively more resistant to visible damage by $\mathrm{H}_{2} \mathrm{O}_{2}$. The calcium ionophore, ionomycin, is capable of inducing identical changes in the microtubules of $\mathrm{PC} 12$ neurites suggesting that $\mathrm{H}_{2} \mathrm{O}_{2}$-mediated changes in microtubule organization in PC 12 neurites are $\mathrm{Ca}^{2+}$ dependent. Finally, the rapidity with which low micromolar $\mathrm{H}_{2} \mathrm{O}_{2}$ induces lysis of NGF-differentiated PC 12 cells is in marked contrast to the observed kinetics of endothelial lysis ${ }^{12,22}$, another potentially important target of oxidants in the CNS. This difference is not accounted for by a diminished capacity of differentiated $\mathrm{PC} 12$ cells to metabolize $\mathrm{H}_{2} \mathrm{O}_{2}$ which is equivalent to that seen with endothelial cells.

\section{MATERIALS AND METHODS}

\section{Description of model - culture methods}

The PC 12 cell line (derived from a rat pheochromocytoma; American Type Culture Collection, Rockville, MD) has been used by many investigators as a cellular model of the neuron ${ }^{3,5,26}$. The undifferentiated PC 12 cells were cultured in either 75 or $150 \mathrm{~cm}^{2}$ flasks pre-coated with rat tail collagen $(0.01 \%$ in $0.1 \mathrm{M}$ acetic acid, 6 $\left.\mu \mathrm{g} / \mathrm{cm}^{2}\right)$ and grown in RPMI 1640 media containing $5 \%$ fetal bovine serum (fbs) and $10 \%$ horse serum (hs) to which was added penicillin and streptomycin. They were passaged by shaking to dislodge adherent cells and cellular clumps were disrupted by vigorous pipetting prior to transfer.

For experiments with differentiated PC 12 cells, 6-well plates were initially plated at confluence with bovine pulmonary artery endothelial cells (AG2791A, National Institute of Aging - Aging Cell Culture Repository, Camden, NJ) for $48-72 \mathrm{~h}$, after which the endothelial cells were removed by exposure to trypsin $(0.05 \%)$ and EDTA $(0.02 \%)$ for $15 \mathrm{~min}$ at $37^{\circ} \mathrm{C}$. Any remaining endothelial cells were lysed by the addition of sterile deionized $\mathrm{H}_{2} \mathrm{O}$. We have found that the endothelial cells left a much better surface to support PC 12 adherence than did rat tail collagen and that this was equally important for the formation and spreading of neurites. After the pretreatment of the 6-well plates, the PC 12 cells were plated at approximately $1.75 \times 10^{5}$ per well in RPMI 1640 media containing $5 \%$ fbs and $10 \%$ hs for $24 \mathrm{~h}$. The PC 12 cells were then allowed to differentiate for 5-7 days in RPMI 1640 containing $1 \%$ hs and $7 \mathrm{~S}$ $\mathrm{NGF}(100 \mathrm{ng} / \mathrm{ml}$; Sigma. St. Louis, MO) and were then ready for the injury studies.

Experiments in which the cells were exposed to a single bolus of $\mathrm{H}_{2} \mathrm{O}_{2}$ in 6-well plates were carried out using modified Gey's buffer (MGB) containing (in mM): $\mathrm{NaCl} 147, \mathrm{KCl} 5, \mathrm{KH}_{2} \mathrm{PO}_{4} 1.9, \mathrm{Na}_{2} \mathrm{HPO}_{4}$ $1.1, \mathrm{MgSO}_{4} 0.3, \mathrm{MgCl}_{2}, 1$, HEPES $10, \mathrm{CaCl}_{2} 1.5$ and glucose 5.5; at $\mathrm{pH}$ 7.4. In some experiments, the cells were exposed to a final concentration of $25 \mu \mathrm{M}$ ionomycin for varying periods of time.

\section{Fluorescence microscopy}

Adherent cells were grown at subconfluence in 6-well plates (Falcon, Becton Dickinson). After varying periods of incubation at $37^{\circ} \mathrm{C}$ under the different experimental conditions, the adherent cells were fixed with $2 \%$ paraformaldehyde and placed on ice for $1 \mathrm{~h}$. The paraformaldehyde was then removed and the cells were washed twice with MGB containing $0.1 \%$ bovine serum albumin (Sigma, St. Louis, MO). The cells were then incubated for $5 \mathrm{~min}$ with MGB containing $1 \%$ bovine serum albumin (BSA) at room temperature. After removal of the MGB plus BSA, the cells were permeabilized with $0.2 \%$ triton $\mathrm{X}-100$ (Tx-100) for $5 \mathrm{~min}$ followed by another $5 \mathrm{~min}$ of exposure to MGB with $1 \%$ BSA after removal of the Tx-100. After an additional series of one to two quick wash steps with MGB plus $0.1 \% \mathrm{BSA}$, the cells were either stained with $165 \mathrm{nM}$ rhodamine phalloidin (Molecular Probes, Junction City, OR) specific for F-actin in microfilaments, for $20 \mathrm{~min}$ at room temperature in the dark or exposed to the appropriate dilution of an antibody to tubulin within microtubules $(1 \mu \mathrm{g} / \mathrm{ml}$ monoclonal mouse anti- $\beta$ tubulin, Boehringer, Mannheim, Indianapolis, IN). After three quick rinses, a second rhodamine-conjugated goat antimouse IgG antibody (Boehringer Mannheim, Indianapolis, IN) 1:50 dilution, was then reacted with the samples to achieve visualization of the stained structures. Coverslips were sealed to each monolayer with $5 \mu \mathrm{l}$ of $90 \%$ glycerol and the samples were viewed with an appropriate filter block on a Nikon optiphot fluorescence microscope. Fluorescence micrographs were taken at $400 \times$ magnification using TMAX-400 film (Kodak, Rochester, NY). Also, staining with a monoclonal antibody to acetylated $\alpha$-tubulin (6-11B-1, a generous gift from Dr. Gianni Piperno, Mt. Sinai School of Medicine. New York, NY) at a $1: 10$ up to $1: 50$ dilution was done in a similar manner.

\section{Scanning electron microscopy}

Samples of whole fixed cells were prepared by fixation with modified Karnovsky's fixative ( $1.5 \%$ glutaraldehyde, $2 \%$ paraformaldehyde in $0.1 \mathrm{M}$ cacodylate buffer, $\mathrm{pH} 7.4$ ) for $1-2 \mathrm{~h}$ at $4^{\circ} \mathrm{C}$ (fixative at room temperature was initially added to warm cells and later chilled to $4^{\circ} \mathrm{C}$. Post-fixation with $1 \% \mathrm{OsO}_{4}$ was done in the same buffer for $1 \mathrm{~h}$ at room temperature. Adherent cells were dehydrated through graded ethanol, critical point dried and sputter coated with a carbon target. Samples were viewed with a scanning electron microscope at 20,000 acceleration voltage.

\section{Quantitation of tubulin depolymerization within PC 12 neurites}

The percentage of neurites demonstrating tubulin depolymerization from a given experimental sample (one well of a 6-well plate) was determined by counting 100 individual neurites (stained with anti- $\beta$-tubulin) at $400 \times$ magnification. Only neurites showing the characteristic pattern of tubulin depolymerization depicted in Fig. 2 of the Results section were counted as showing tubulin depolymerization in the determination. Also, care was taken to trace the course of individual neuritic processes so that the same process would not be counted more than once.

\section{Viability determinations}

The Live-Dead assay (Molecular Probes, Inc., Junction City, OR) was used to determine viability because it reduces manipulation of the adherent, differentiated PC 12 cells. The assay utilized two different fluorophores, ethidium homodimer and calcein-AM, both of which could be easily visualized with a fluorescent microscope using a fluorescein-compatible filter block. Ethidium homodimer, a DNA stain, stained the nuclei of dead cells a bright red color. Calcein-AM, the acetoxymethyl ester of calcein was taken up and cleaved by non-specific esterases to the fluorescent (green color)-free acid form only by viable cells. Utilizing $8 \mu \mathrm{M}$ ethidium homodimer and $4 \mu \mathrm{M}$ calcein-AM we were able to achieve good discrimination between dead and alive cells after a $15-\mathrm{min}$ incubation at $37^{\circ} \mathrm{C}$. One hundred adherent cells per well in situ were then counted, and the percentage of viable (green) cells was determined. Controls in which adherent PC 12 cells underwent detergent lysis with Triton X-100 demonstrated $100 \%$ ethidium staining and consistent loss of the ability to concentrate and cleave calcein-AM.

\section{$\mathrm{H}_{2} \mathrm{O}_{2}$ consumption measurements}

To compare the overall status of cellular antioxidant defenses in adherent, differentiated PC 12 cells with adherent endothelial cells, the rate of $\mathrm{H}_{2} \mathrm{O}_{2}$ consumption was determined by the technique of Hyslop and Sklar ${ }^{15}$. Briefly, the non-fluorescent substrate $p$-hydroxyphenylacetate (PHPA, Sigma Chemical Co., St. Louis, MO) was oxidized to the stable fluorescent product $2,2^{\prime}$-dihydroxybiphenyl- 
5,5'-diacetate, (PHPA) $)_{2}$, by the enzymatic reduction of $\mathrm{H}_{2} \mathrm{O}_{2}$ by horseradish peroxidase (Type IV Sigma). After adherent cells were exposed to a range of $\mathrm{H}_{2} \mathrm{O}_{2}$ concentrations, $10-50 \mu \mathrm{l}$ of supernatant from each well (6-well plates) was added to $180.5 \mu \mathrm{g} / \mathrm{ml}$ PHPA and $58 \mu \mathrm{g} / \mathrm{ml}$ of horseradish peroxidase in $2 \mathrm{ml}$ of modified Gey's buffer. Assays were performed in plastic cuvettes containing a magnetic starhead stir bar. The samples were placed in a stirred thermostatted sample chamber of an SLM series $8000 \mathrm{C}$ spectrofluorometer at $37^{\circ} \mathrm{C}$. Excitation and emission wave lengths were 323 and 400 $\mathrm{nm}$, respectively.

\section{RESULTS}

\section{$\mathrm{H}_{2} \mathrm{O}_{2}$ induces depolymerization of microtubules in $\mathrm{PC} 12$ neurites}

PC 12 cells which had undergone differentiation in the presence of NGF for 5-6 days demonstrated a uniform pattern of microtubule staining within their neurites using a monoclonal antibody to $\beta$-tubulin (Fig. 1). When PC 12 cells were exposed to a bolus of $\mathrm{H}_{2} \mathrm{O}_{2}$ (final concentration ranging from $100 \mu \mathrm{M}$ to $5 \mathrm{mM}$ ), characteristic changes affecting microtubule organization developed over a 3-4 h time course. Initially, the homogeneous microtubule staining with the antibody was lost and was replaced by a pattern of discontinuous staining which demonstrated a high degree of periodicity (Fig. 2). Later in the course of injury, the remaining areas of intense microtubule staining were also lost leaving a 'ghost-like' neurite remnant (Fig. 3). This pattern of events affecting tubulin was consistent with tubulin depolymerization which was initiated at different points along the long axis of the neurite. Blebbing of the PC 12 cell bodies and along neurites also oc- curred after exposure to $\mathrm{H}_{2} \mathrm{O}_{2}$. The blebs appeared to contain tubulin (Fig. 4). Scanning electron microscopy demonstrated fragmentation of neurites in injured $\mathrm{PC}$ 12 cells at time points when depolymerization of neuritic microtubules was nearly complete (Fig. 5).

When the percentage of neurites (from 100 neurites counted per well) which showed some degree of disruption (tubulin depolymerization) were quantitated, an interesting injury pattern became evident. The entire dose range of $\mathrm{H}_{2} \mathrm{O}_{2}$ studied was capable of disrupting most of the neurites by 4-6 h. Higher concentrations of the oxidant produced the changes more rapidly, although the net effect did not appear to be different from that produced by the lower concentrations over a longer time course (Fig. 6).

\section{Microfilaments and $\mathrm{H}_{2} \mathrm{O}_{2}$ injury to PC 12 cells}

Since microfilaments are known to be early, prominent targets of oxidant injury in other cellular models $^{9-11,13,23-25}$, we also examined microfilament organization in PC 12 cells exposed to $\mathrm{H}_{2} \mathrm{O}_{2}$. Uninjured PC 12 cells stained with rhodamine phalloidin (which binds to polymerized actin) demonstrated prominent microspikes containing polymerized actin on some cell bodies and also along neurites which were oriented perpendicular to the long axis of the neurite (Fig. 7A). $\mathrm{H}_{2} \mathrm{O}_{2}$ exposure damaged many of the neuritic microspikes, although some microspikes remained relatively unchanged after injury even at time points when microtubule depolymerization was largely complete

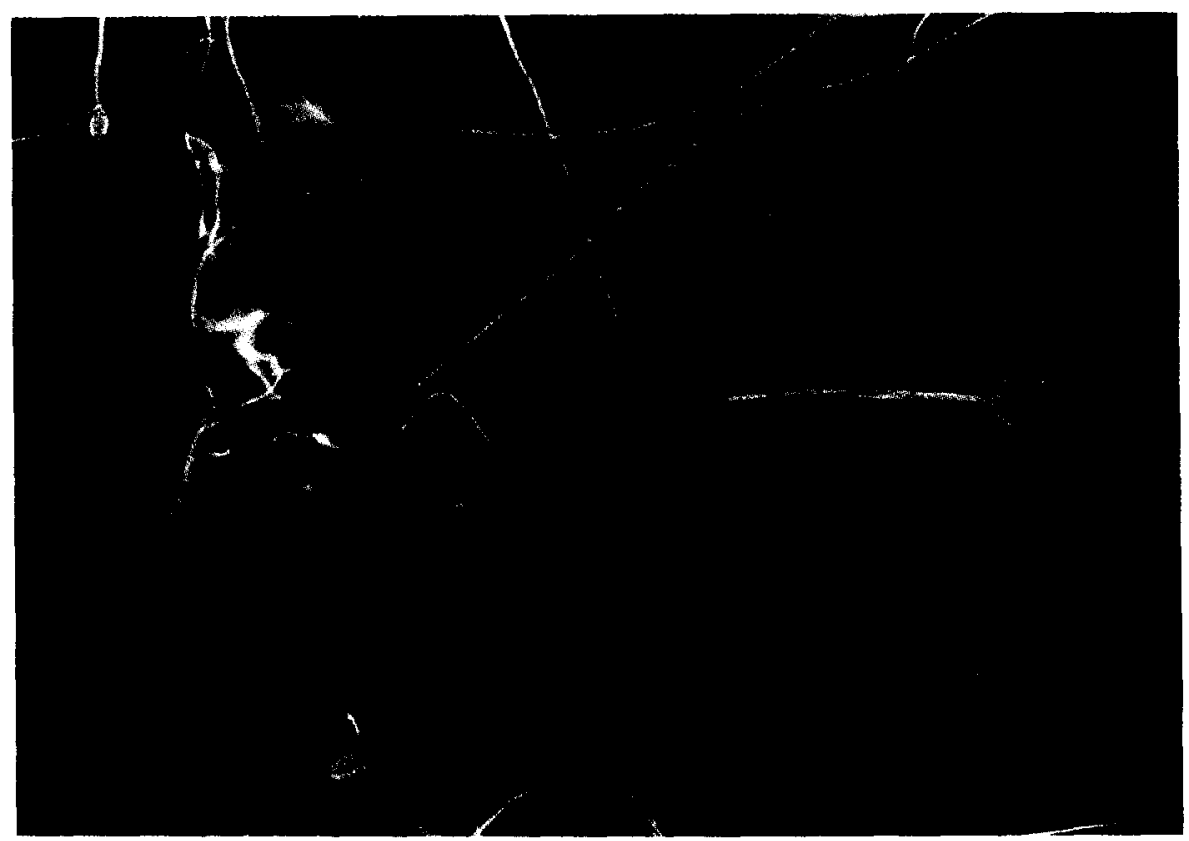

Fig. 1. Fluorescence micrograph of uninjured (control) PC 12 cells stained using a double antibody technique for tubulin (murine monoclonal antibody to $\beta$-tubulin followed by rhodamine-conjugated goat anti-mouse IgG). $300 \times$ magnification. 

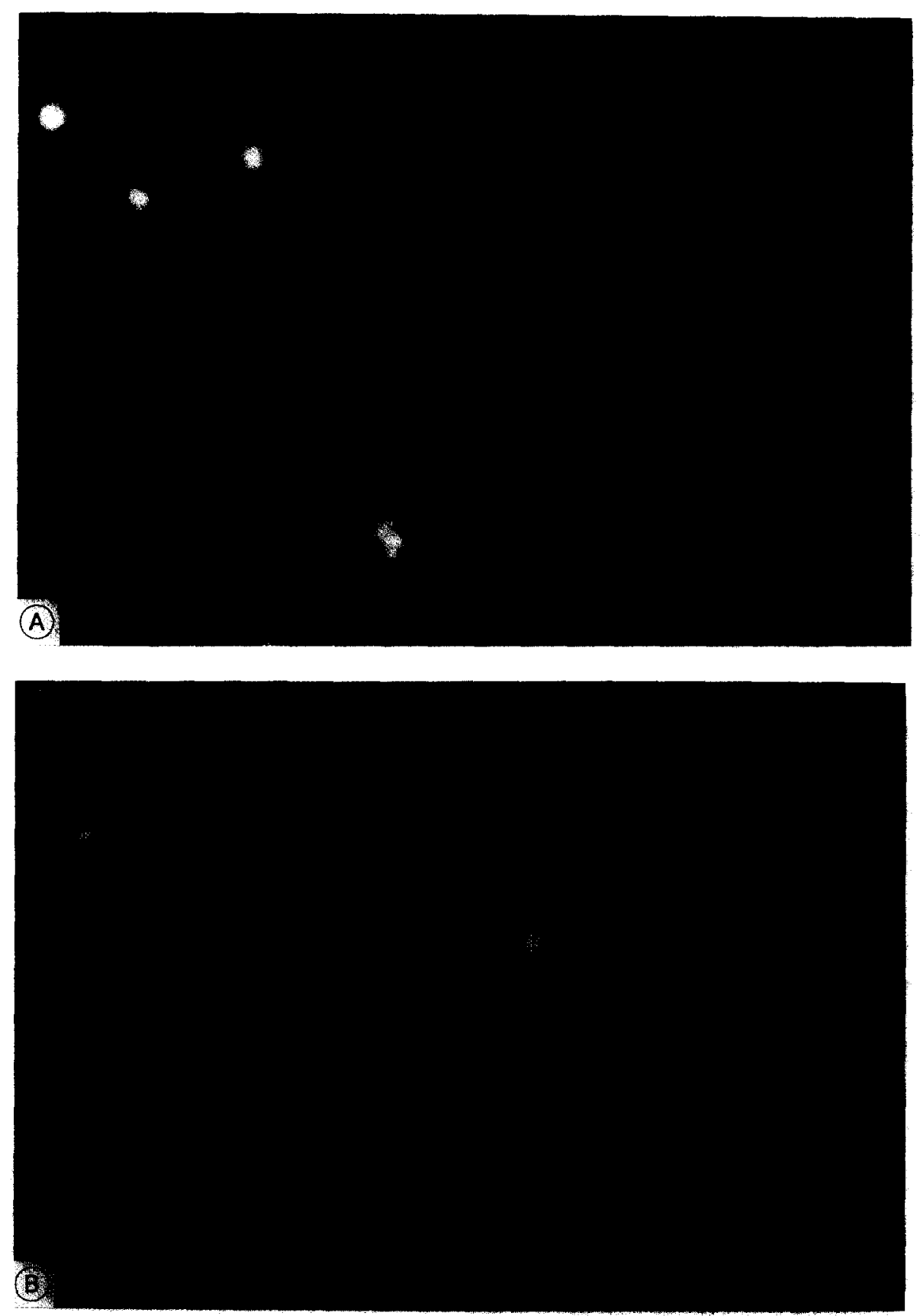

Fig. 2. Fluorescence micrographs of $\mathrm{PC} 12$ cells after $\mathrm{H}_{2} \mathrm{O}_{2}$ exposure stained using a double antibody technique for tubulin. A: microtubule organization in neurites $3 \mathrm{~h}$ after exposure to $250 \mu \mathrm{M} \mathrm{H}_{2} \mathrm{O}_{2}$. Note the periodic breaks in microtubule staining along the injured neurites. $300 \times$ magnification. B: microtubule organization in neurites $4 \mathrm{~h}$ after exposure to $100 \mu \mathrm{M} \mathrm{H}_{2} \mathrm{O}_{2}$. Note the periodic breaks in microtubule staining along the injured neurites. $300 \times$ magnification.

(Fig. 7B). In fact, microspikes containing F-actin often appeared to be the only remaining elements in many of the injured neurites at later time points.

Hypothesis: microtubule depolymerization within $\mathrm{H}_{2} \mathrm{O}_{2}$ injured neurites is initiated by elevation of cytosolic $\mathrm{Ca}^{2+}$

Earlier work with $\mathrm{P}_{388 \mathrm{D}_{1}}$ and endothelial cells demonstrated that $\mathrm{H}_{2} \mathrm{O}_{2}$ can cause elevation of cytosolic $\mathrm{Ca}^{2+}\left(\left[\mathrm{Ca}^{2+}\right]_{\mathrm{i}}\right)$ levels ${ }^{10,14}$. Microtubule depolymerization occurred in adherent endothelial cells under conditions (exposure to either $\mathrm{H}_{2} \mathrm{O}_{2}>5 \mathrm{mM}$, or to the $\mathrm{Ca}^{2+}$ ionophore, $5 \mu \mathrm{M}$ ionomycin in the presence of metabolic inhibition) which produced significant increases in $\left[\mathrm{Ca}^{2+}\right]_{\mathrm{i}}$ in the range of $1 \mu \mathrm{M}$ or greater as measured with the fluorescent $\mathrm{Ca}^{2+}$ indicator, Quin $2^{10}$.

We hypothesized that if elevation of $\left[\mathrm{Ca}^{2+}\right]_{\mathrm{i}}$ was responsible for the dramatic changes in microtubule organization within neurites of PC 12 cells exposed to $\mathrm{H}_{2} \mathrm{O}_{2}$, elevation of $\left[\mathrm{Ca}^{2+}\right]_{1}$ independent of oxidant 


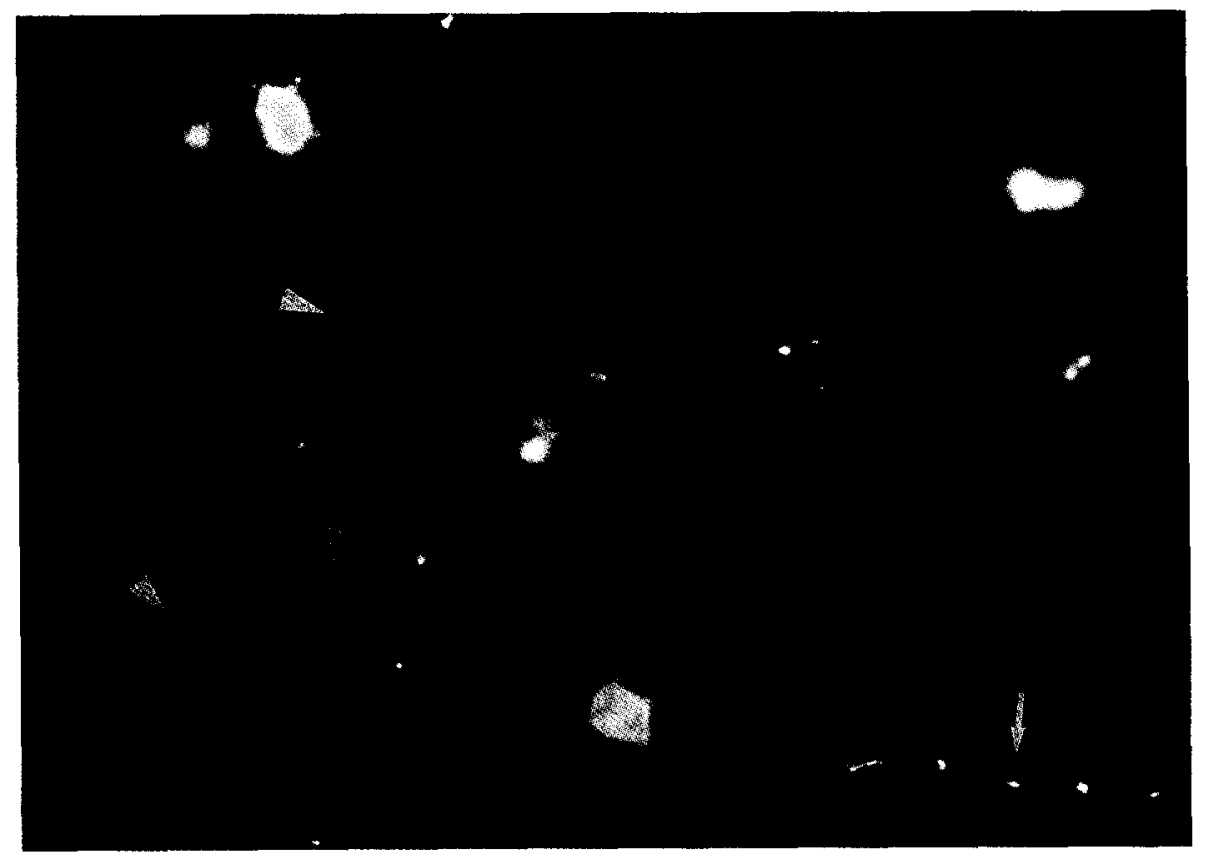

Fig. 3. Fluorescence micrograph of PC 12 cells after $\mathrm{H}_{2} \mathrm{O}_{2}$ exposure stained using a double antibody technique for tubulin. PC 12 cells $4 \mathrm{~h}$ after addition of $250 \mu \mathrm{M} \mathrm{H}_{2} \mathrm{O}_{2}$. Note the loss of tubulin staining in the neurite remnant (arrowhead) as compared to the periodic pattern of tubulin staining present on another neurite nearby (arrow). $300 \times$ magnification.

exposure should reproduce the same pathologic changes. Adherent PC 12 cells exposed to $25 \mu \mathrm{M}$ ionomycin for 5-30 min demonstrated rapid disruption of microtubules within almost all $(90 \%)$ neurites after only $15 \mathrm{~min}$ of exposure to the $\mathrm{Ca}^{2+}$ ionophore (Fig. 8A). The depolymerization of microtubules in PC 12 neurites induced by $\mathrm{Ca}^{2+}$ ionophore also exhibited the same high degree of periodicity as that seen following
$\mathrm{H}_{2} \mathrm{O}_{2}$ injury. When $\mathrm{PC} 12$ cells were exposed to 25 $\mu \mathrm{M}$ ionomycin for $15 \mathrm{~min}$ in $\mathrm{MGB}$ prepared without the addition of $\mathrm{Ca}^{2+}$ plus the addition of $100 \mu \mathrm{M}$ EGTA to further deplete $\mathrm{Ca}^{2+}$, depolymerization of tubulin within neurite microtubules did not occur (Fig. 8B). The $\mathrm{Ca}^{2+}$-depleted conditions alone did not affect PC 12 morphology or the integrity of neuritic microtubules (Fig. 8C).

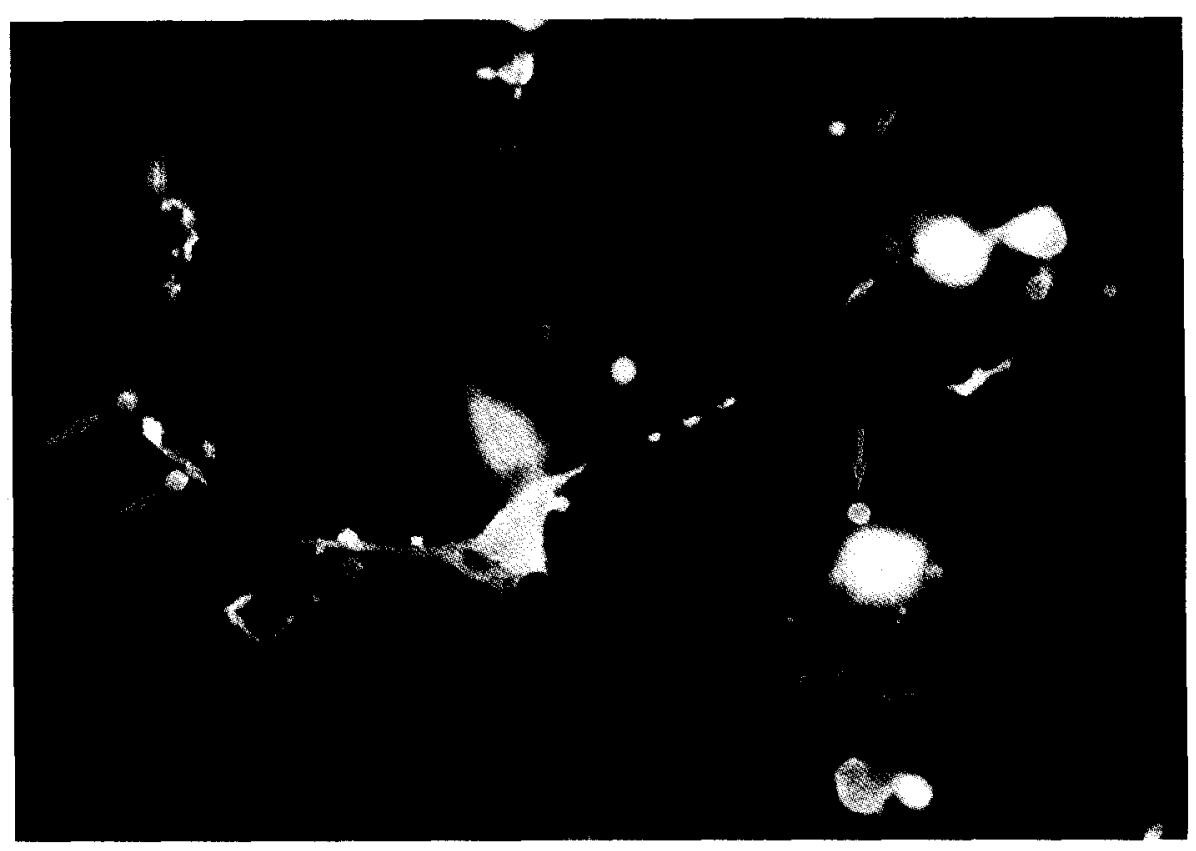

Fig. 4. Fluorescence micrograph of $\mathrm{PC} 12$ cells after $\mathrm{H}_{2} \mathrm{O}_{2}$ exposure stained using a double antibody technique for tubulin. PC 12 cells $4 \mathrm{~h}$ after addition of $500 \mu \mathrm{M} \mathrm{H}_{2} \mathrm{O}_{2}$. Note the brightly stained blebs on cell bodies and neurites (arrows). $300 \times$ magnification. 
Viability of $\mathrm{PC} 12$ cells after $\mathrm{H}_{2} \mathrm{O}_{2}$ injury

We next examined changes in the viability of PC 12 cells after $\mathrm{H}_{2} \mathrm{O}_{2}$ exposure to determine the relationship between neurite disruption and neuronal death after oxidant exposure. To minimize manipulation of the cells we used a relatively new fluorescent method (Live-Dead Assay, Molecular Probes, Inc., Junction
City, OR; see Materials and Methods). Experiments with exposure to $0-5 \mathrm{mM} \mathrm{H}_{2} \mathrm{O}_{2}$ over a 6-h time course revealed that there was a dose-dependent effect on the rate of PC 12 cell killing. Doses of $\mathrm{H}_{2} \mathrm{O}_{2}$ as low as 100 $\mu \mathrm{M}$ killed nearly $40 \%$ of the cells by $6 \mathrm{~h}$ (see Fig. 9).

Comparison of the data in Fig. 9 with that in Fig. 6 above demonstrates that in general, neurite disruption
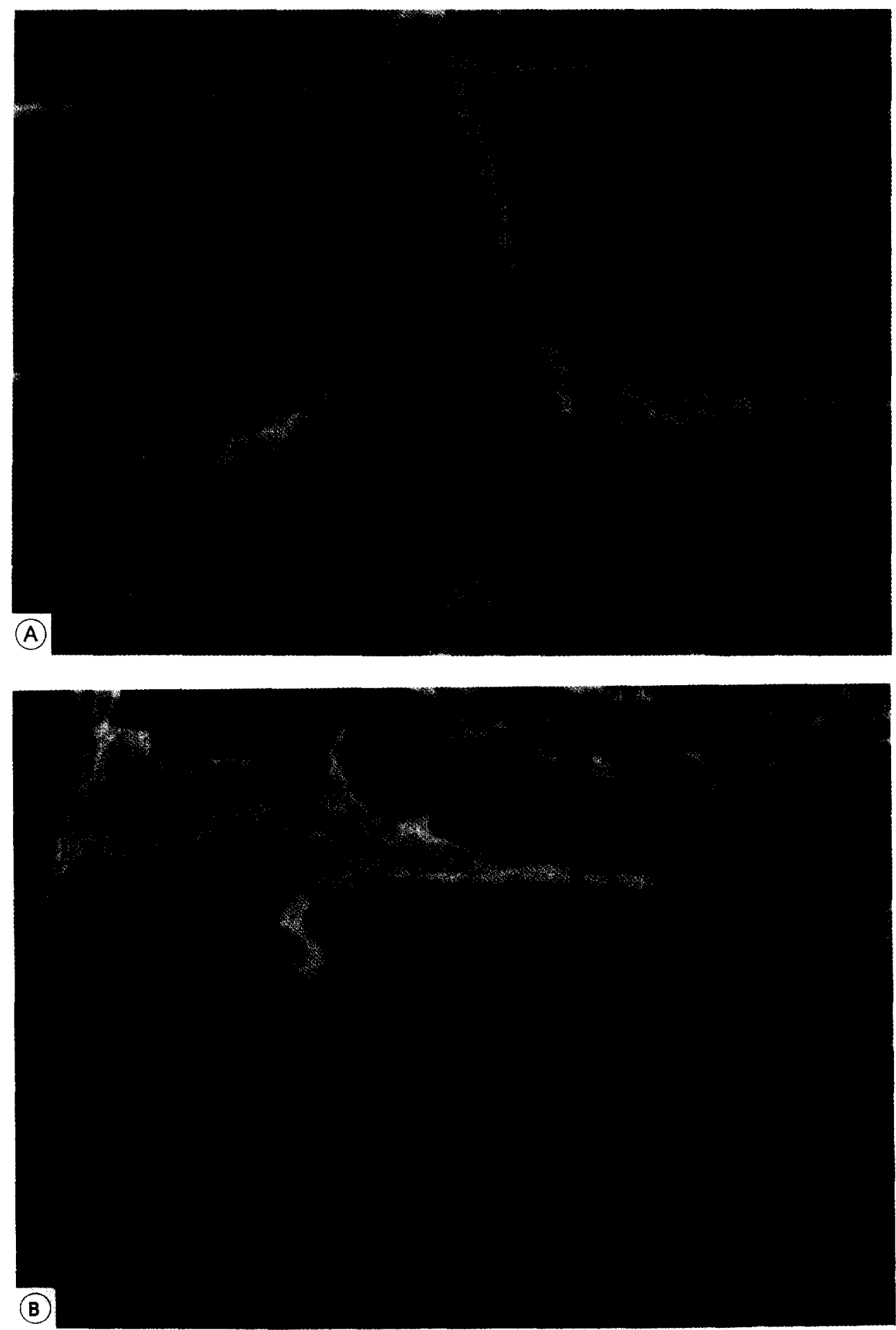

Fig. 5. Scanning electron micrographs of PC 12 cells. A: uninjured controls. $3500 \times$ magnification. $B: 3$ h after addition of $100 \mu \mathrm{M} \mathrm{H}_{2} \mathrm{O}_{2}$. $3500 \times$ magnification. Note the fragmentation and apparent flattening of the injured neurites. 
preceded loss of PC 12 cell viability and was consistent with the hypothesis that neurite loss or disruption after injury may play an important role in neuronal death. To test this hypothesis, we examined the effect of the microtubule-stabilizing agent, Taxol ${ }^{29}$ on neuritic morphology and PC 12 cell viability over a 6-h time course of oxidant injury. Exposure of PC 12 cells to $5 \mu \mathrm{M}$ Taxol (added $15 \mathrm{~min}$ before oxidant addition) during the time course of $\mathrm{H}_{2} \mathrm{O}_{2}$ exposure prevented the microtubule depolymerization seen with $\mathrm{H}_{2} \mathrm{O}_{2}$ injury (Fig. $10 \mathrm{~A}-\mathrm{C})$. Stabilization of microtubule morphology with Taxol did not alter the rate or extent of killing of PC 12 cells by $\mathrm{H}_{2} \mathrm{O}_{2}$ (Fig. 11). Thus, neuritic microtubule depolymerization is not an essential intermediate step in $\mathrm{PC} 12$ cell lysis induced by $\mathrm{H}_{2} \mathrm{O}_{2}$.

\section{Antioxidant activity of PC 12 cells}

The rapidity with which low micromolar concentrations of $\mathrm{H}_{2} \mathrm{O}_{2}$ (e.g. $\left.100 \mu \mathrm{M}\right)$ produced cytotoxicity in the differentiated PC 12 cells was in striking contrast to the kinetics of $\mathrm{H}_{2} \mathrm{O}_{2}$-mediated killing of endothelial cells by similar concentrations of the oxidant ${ }^{10,19}$. Endothelial cytotoxicity secondary to low micromolar concentrations of $\mathrm{H}_{2} \mathrm{O}_{2}$ was typically manifest by $18-24 \mathrm{~h}$ rather than $4-6 \mathrm{~h}$ as was seen in the PC 12 cells. This observation led us to question whether the two cell types had different abilities to consume exogenous $\mathrm{H}_{2} \mathrm{O}_{2}$.

Adherent, differentiated PC 12 cells grown in 6-well plates as described above were compared with equivalent numbers of adherent endothelial cells $(6.6 \pm 0.4 \times$ $10^{5} /$ well vs. $6.4 \pm 0.1 \times 10^{5} /$ well, respectively; $n=5$ ) with respect to their ability to consume a given load of $\mathrm{H}_{2} \mathrm{O}_{2}(100 \mu \mathrm{M}$ and $1 \mathrm{mM})$ given as a bolus. Disappearance of the added $\mathrm{H}_{2} \mathrm{O}_{2}$ from the cellular buffer was monitored fluorometrically using the assay of Hyslop and Sklar ${ }^{15}$ (Fig. 12A,B). The measurements were also conducted in the presence of $12 \mathrm{mM} \mathrm{3-amino-}$ 1,2,4-triazole ${ }^{30}$, the potent inhibitor of catalase, to determine catalase-dependent $\mathrm{H}_{2} \mathrm{O}_{2}$ consumption.

There were no obvious differences in the pattern of $\mathrm{H}_{2} \mathrm{O}_{2}$ metabolism by either cell type even with relatively low $(100 \mu \mathrm{M})$ or high $(1 \mathrm{mM})$ concentrations of $\mathrm{H}_{2} \mathrm{O}_{2}$. Catalase appeared to be responsible for almost all $\mathrm{H}_{2} \mathrm{O}_{2}$ consumption by both cell types under the adherent conditions and at both concentrations of the oxidant.

\section{DISCUSSION}

In this study we have demonstrated that PC 12 cells differentiated by treatment with NGF to a neuronal phenotype are very sensitive to injury by $\mathrm{H}_{2} \mathrm{O}_{2}$. Microtubule depolymerization in the majority of PC 12 neurites was initiated by exposure to concentrations of $\mathrm{H}_{2} \mathrm{O}_{2}$ as low as $100 \mu \mathrm{M}$. Higher concentrations of $\mathrm{H}_{2} \mathrm{O}_{2}$ were associated with a more rapid progression and development of the neuritic disruption but the net effect of the lower concentrations appeared to be the same as the higher. Depolymerization of neuritic microtubules and plasma membrane blebbing along the neurites and cell bodies of injured cells preceded cell lysis. Experiments with the microtubule-stabilizing agent, Taxol, demonstrated that microtubule disrup-

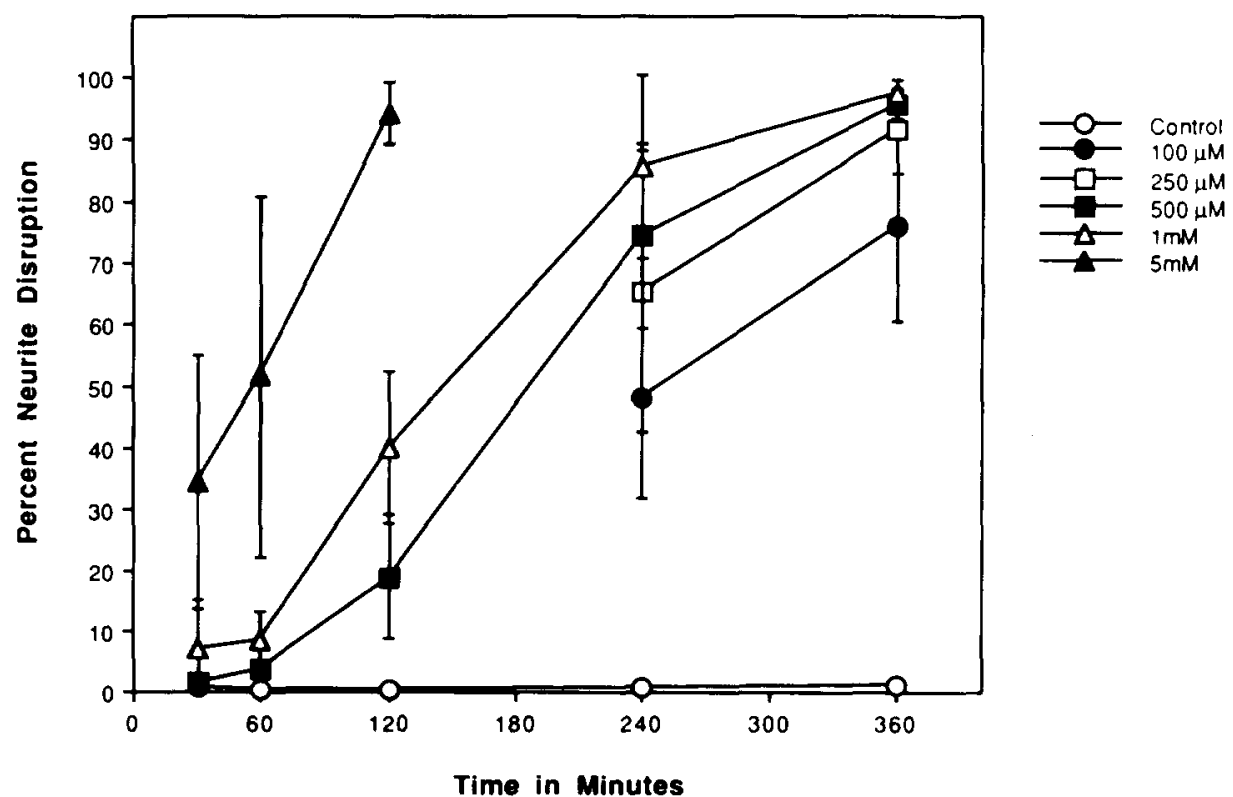

Fig. 6. PC 12 neurite disruption (microtubule depolymerization) after $\mathrm{H}_{2} \mathrm{O}_{2}$ exposure. Each data point represents the mean \pm S.D. of $n=5$ separate determinations. 

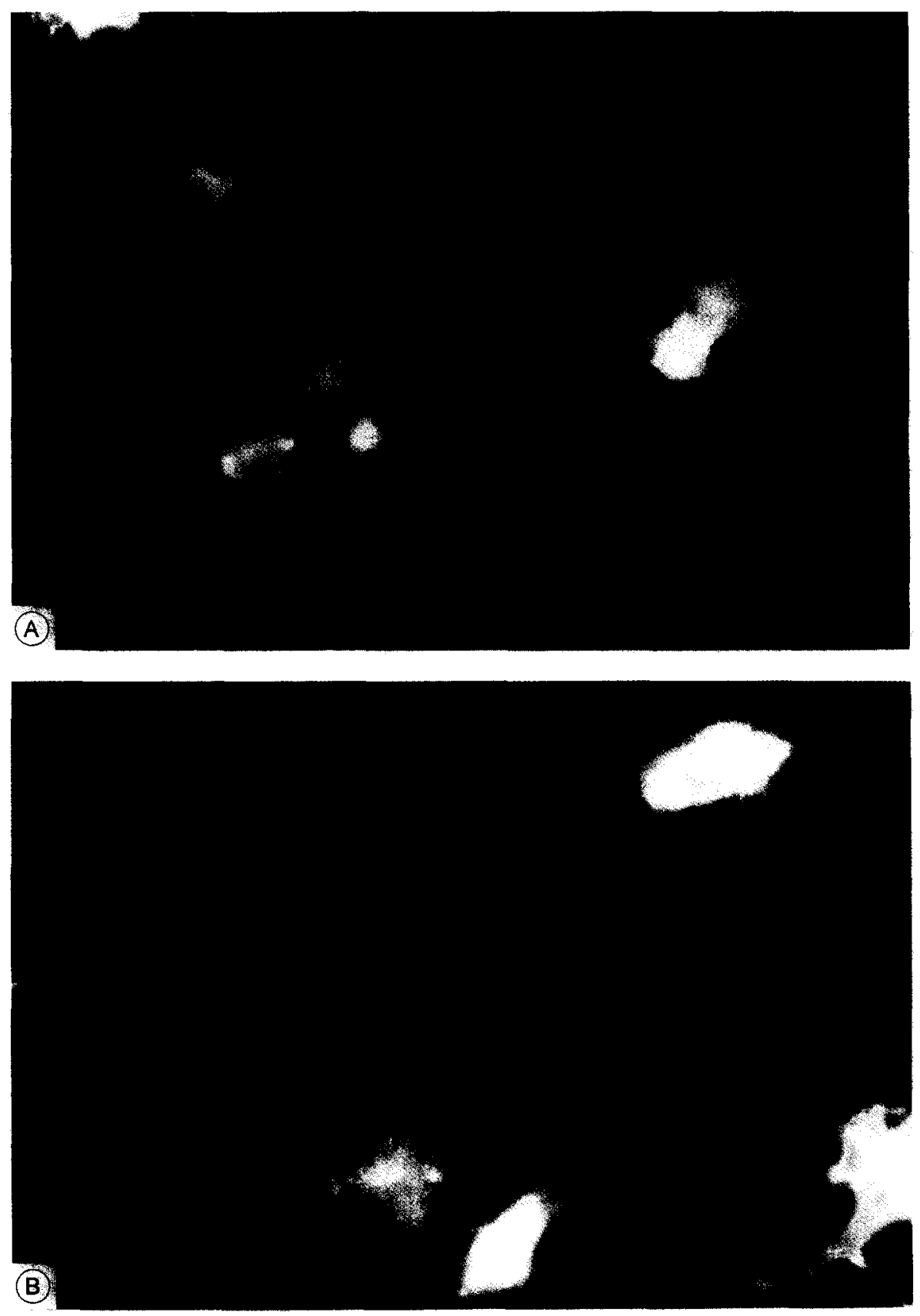

Fig. 7. Fluorescence micrographs of PC 12 cells stained with rhodamine phalloidin. A: uninjured controls. Note the prominent microspikes (arrows) which contain polymerized actin. $300 \times$ magnification. B: PC 12 cells $4 \mathrm{~h}$ after addition of $500 \mu \mathrm{M} \mathrm{H}_{2} \mathrm{O}_{2}$ stained with rhodamine phalloidin. Note the persistence of some microspikes where essentially all other components of the injured neurite have disappeared (arrow). $300 \times$ magnification.

tion within injured neurites does not play a necessary role in PC 12 cell lysis induced by $\mathrm{H}_{2} \mathrm{O}_{2}$.

It is interesting that there was an apparent flattening as well as fragmentation of neurites from injured
PC 12 cells (seen in scanning electron microscopy) at time points when oxidant-induced microtubule depolymerization was nearly complete. This implies that the normal three-dimensional architecture of the neurite

Fig. 8. Fluorescence micrographs of PC 12 cells stained with a double antibody technique for tubulin. A: the cells were exposed to Ca ${ }^{2+}$ ionophore $(25 \mu \mathrm{M}$ ionomycin) for $15 \mathrm{~min}$ prior to fixation and staining. Note the almost universal disruption (depolymerization) of microtubules in neurites and its similarity to the pattern seen with $\mathrm{H}_{2} \mathrm{O}_{2}$ injury. $\mathrm{B}$ : the cells were exposed to identical conditions as in $\mathrm{A}$ except the experimental buffer did not contain added $\mathrm{Ca}^{2+}$ and was further depleted of $\mathrm{Ca}^{2+}$ by the addition of a final concentration of $100 \mu \mathrm{M}$ EGTA at pH 7.4. C: the cells were exposed to the altered buffer conditions in B without exposure to ionomycin. $270 \times$ magnification. 

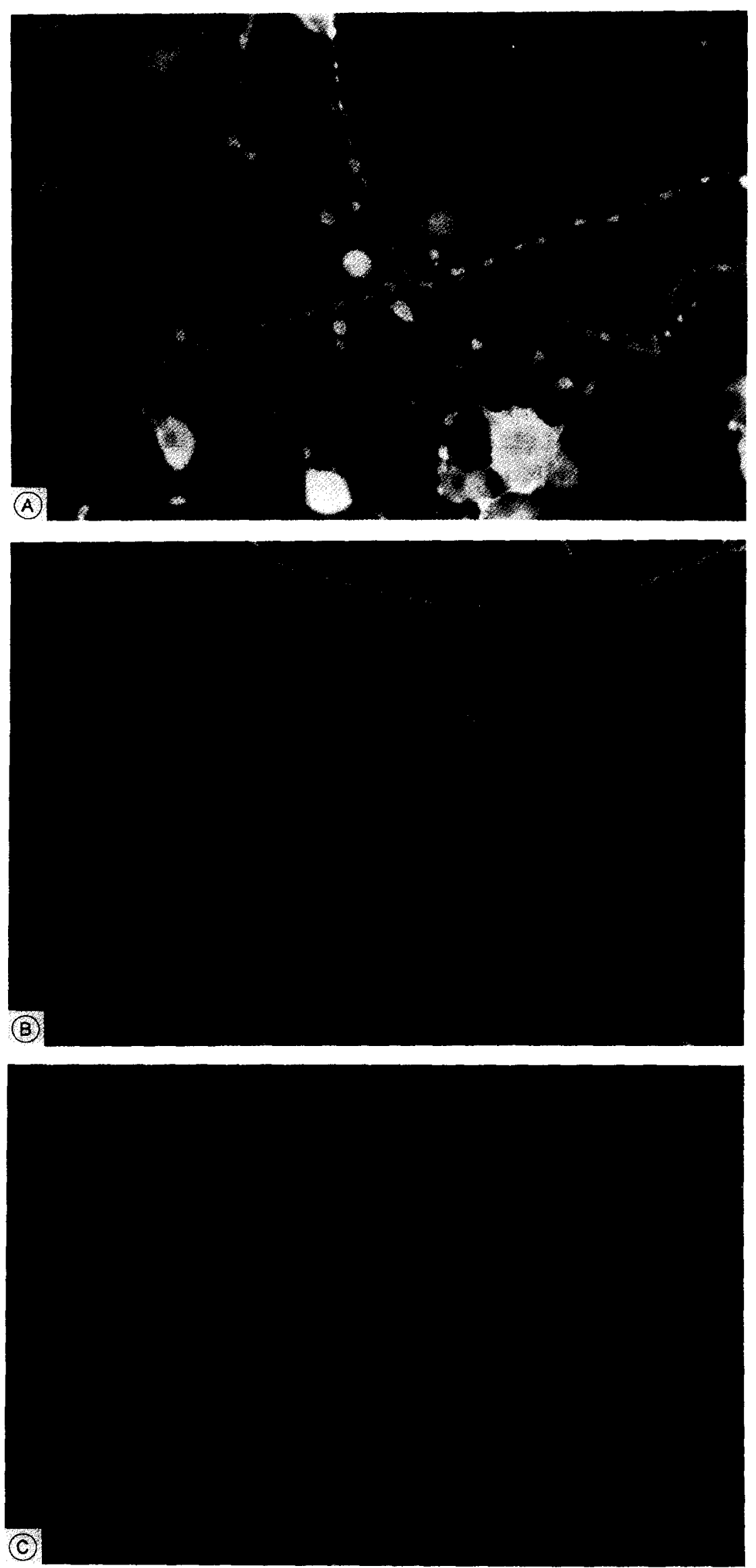


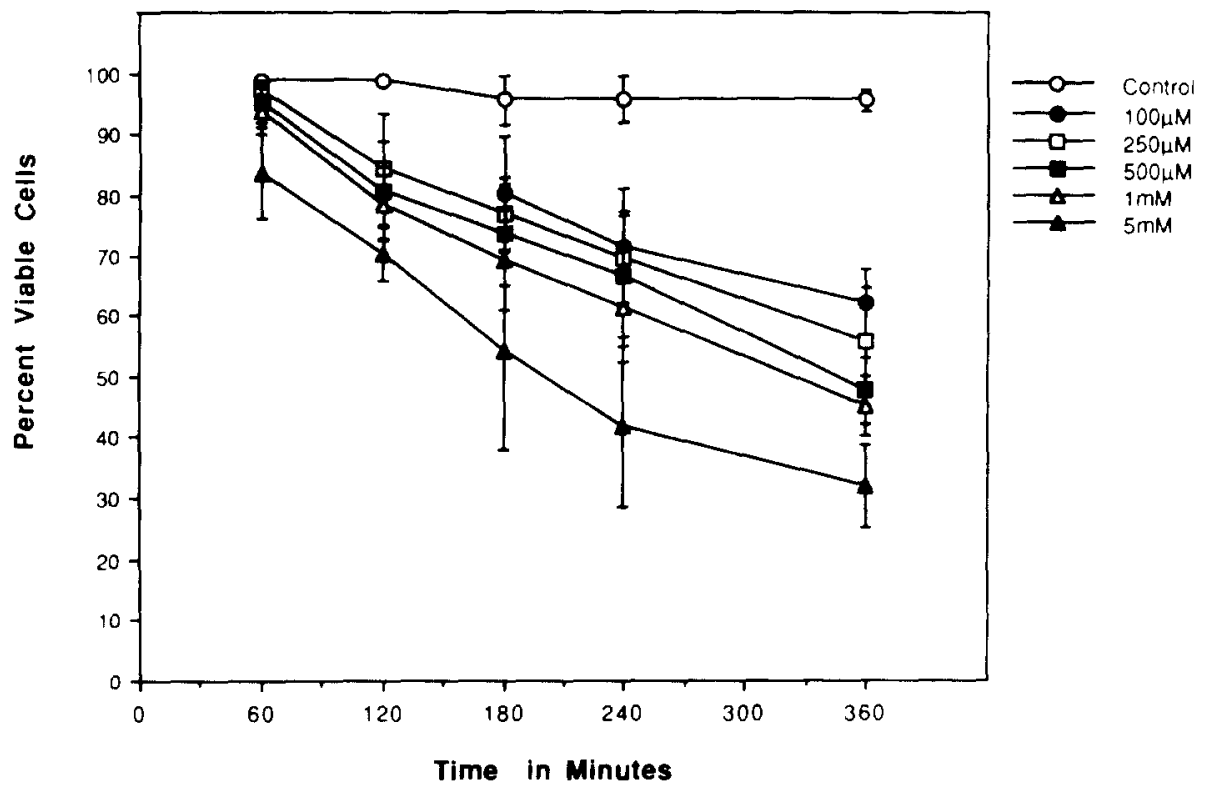

Fig. 9. Effect of $\mathrm{H}_{2} \mathrm{O}_{2}$ on $\mathrm{PC} 12$ cell viability. Each data point represents the mean \pm S.D. of $n=5$ separate determinations.

largely depends upon the presence of intact microtubules. The relative stability of actin filaments present in neuritic microspikes in response to $\mathrm{H}_{2} \mathrm{O}_{2}$ was in contrast to the sensitivity of actin filaments in other non-neuronal cell types to oxidant-mediated disruption $^{9-11,13,23-25}$. Visualization of the actin-containing cytoskeleton in the cell bodies of PC 12 cells was limited in these experiments. It appears that actin filaments in microspikes may represent actin-containing structures which are relatively more resistant to oxidant stress.

The pattern of tubulin depolymerization induced by $\mathrm{H}_{2} \mathrm{O}_{2}$ injury in the neurites of differentiated PC 12 cells is quite interesting. The $\mathrm{Ca}^{2+}$ ionophore, ionomycin, was capable of inducing $\mathrm{Ca}^{2+}$-dependent microtubule depolymerization in neurites of treated cells in a manner similar to $\mathrm{H}_{2} \mathrm{O}_{2}$, although the kinetics of the process were much faster than for the oxidant. This supported the hypothesis that $\mathrm{H}_{2} \mathrm{O}_{2}$ disrupts $\left[\mathrm{Ca}^{2+}\right]_{i}$ homeostasis in differentiated PC 12 cells and that the oxidant-mediated process occurs more slowly and with less uniformity than that seen with ionomycin treatment. These observations with PC 12 cells are not inconsistent with our earlier findings in the $\mathrm{P}_{388 \mathrm{D}_{1} \text { cell }}$ line demonstrating that oxidant stress can cause a release of $\mathrm{Ca}^{2+}$ from an intracellular pool, thus alter- ing the set point for $\mathrm{Ca}^{2+}$ within injured cells ${ }^{14}$. Further confirmation of this hypothesis will require direct monitoring of $\left[\mathrm{Ca}^{2+}\right]_{\mathrm{i}}$ in PC 12 neurites during $\mathrm{H}_{2} \mathrm{O}_{2}$ injury. Colchicine, $5 \mu \mathrm{g} / \mathrm{ml}$ (data not shown), induced a similar pattern of microtubule disruption after $2 \mathrm{~h}$ in neurites to that seen with ionomycin (Fig. 8A) or after $\mathrm{H}_{2} \mathrm{O}_{2}$ exposure (Fig. 2B) and progressed after 4-6 $\mathrm{h}$ to nearly complete loss of immunostaining for tubulin which also occurred as injury progressed after exposure to ionomycin or $\mathrm{H}_{2} \mathrm{O}_{2}$. This observation provided further confirmation that the injury was inducing depolymerization of neuritic microtubules. The highly ordered pattern of depolymerization seen with ionomycin or $\mathrm{H}_{2} \mathrm{O}_{2}$ in these experiments implies that the organization of tubulin within individual microtubules somehow favors a highly periodic distribution of initiation sites for depolymerization. Recent work demonstrating the presence of tubulins within neurites which have been altered by post-translational modification to a more stable form (e.g. acetylated a-tubulin) suggests that there may be sites within a given tubulin polymer which are more or less stable to the effects of cold or elevated $\left[\mathrm{Ca}^{2+}\right]_{i}^{3}$. Antibodies directed at some of these modified tubulins have demonstrated intermittent staining patterns along neurites which are similar to the periodic pattern seen in our injury model ${ }^{4}$. We

Fig. 10. Taxol prevention of $\mathrm{H}_{2} \mathrm{O}_{2}$-induced microtubule disruption. Fluorescence micrographs of PC12 cells stained with a double antibody technique for tubulin were obtained as described in methods. A: cells $2 \mathrm{~h}$ after exposure to $100 \mu \mathrm{M} \mathrm{H}_{2} \mathrm{O}_{2}$. Note the characteristic pattern of microtubule disruption in the neurites of the injured cells. B: cells after $2 \mathrm{~h}$ of treatment with $5 \mu \mathrm{M}$ Taxol and $100 \mu \mathrm{M} \mathrm{H} \mathrm{O}_{2}$. Note the presence of intact neurites with a continuous staining pattern for tubulin. This effect of Taxol was also seen at 4 and $6 \mathrm{~h}$ after oxidant exposure in $>90 \%$ of cells examined. C: uninjured controls exposed for $2 \mathrm{~h}$ to $5 \mu \mathrm{M}$ Taxol. Note the presence of intact neurites with a continuous pattern of tubulin staining. 

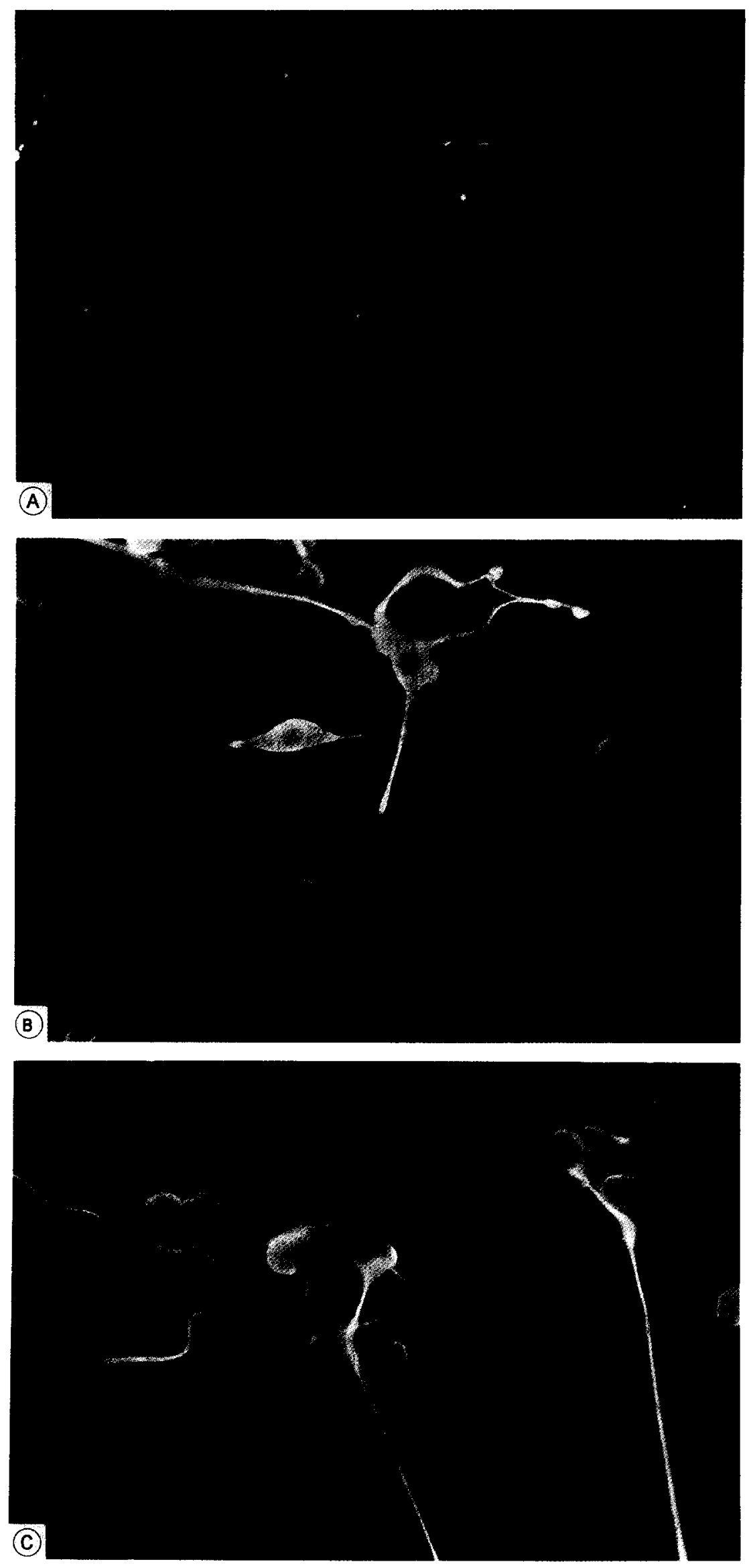


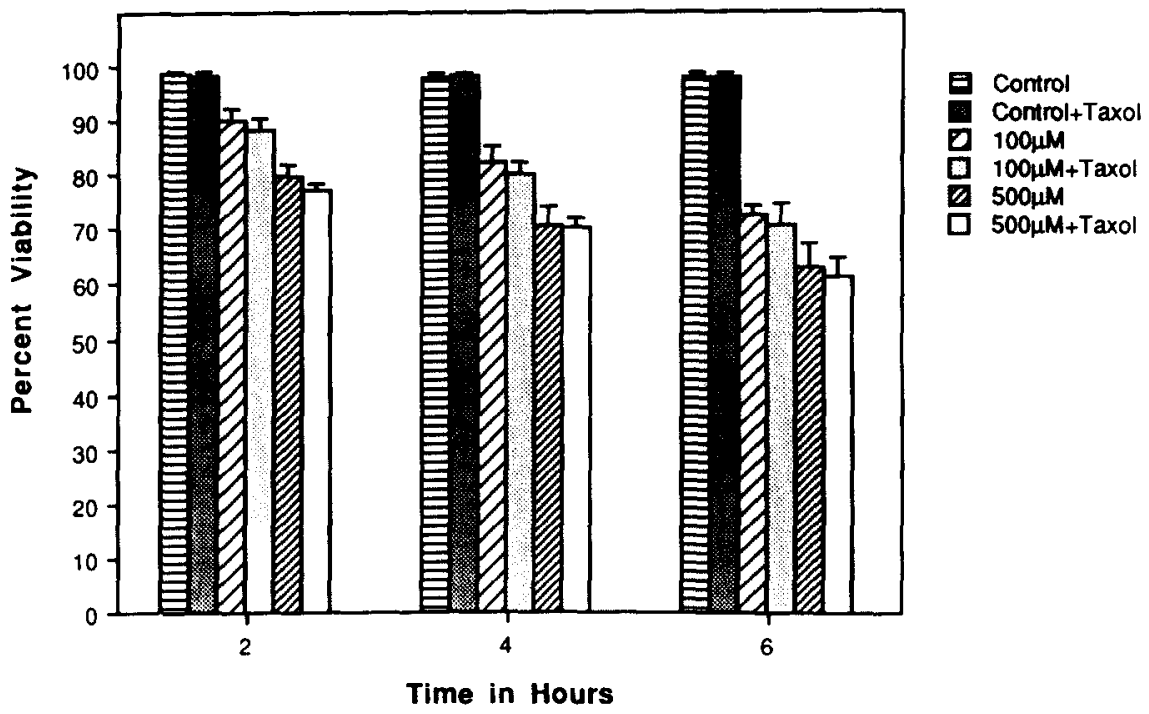

Fig. 11. The effect of microtubule stabilization with $5 \mu \mathrm{M}$ Taxol on PC 12 cell viability following $\mathrm{H}_{2} \mathrm{O}_{2}$ exposure. Each bar represents the mean + S.D. of $n=5$ separate determinations. $100 \mu \mathrm{M}=100 \mu \mathrm{M} \mathrm{H}_{2} \mathrm{O}_{2}, 500 \mu \mathrm{M}=500 \mu \mathrm{M} \mathrm{H}_{2} \mathrm{O}_{2} ;$ Taxol $=5 \mu \mathrm{M}$ Taxol.

have examined the staining pattern of microtubules in differentiated PC 12 neurites stained with the monoclonal antibody 6-11-B-1 which stains acetylated $\alpha$ tubulin and found that it produces a uniform staining pattern identical to staining with the monoclonal anti $\beta$-tubulin, indicating that acetylated $\alpha$-tubulin is uniformly distributed in the microtubules of PC 12 neurites (data not shown). This uniform pattern of staining ${ }^{1}$ is in contrast to the discontinuous pattern of distribution of acetylated $\alpha$-tubulin seen in cerebellar granule cell cultures stained with the monoclonal antibody $6-11-B 1^{4}$. Other factors which may play a role in determining the pattern of tubulin depolymerization seen in these experiments include the microtubule-as- sociated proteins called STOPs (stable-tubule only polypeptides) ${ }^{21}$. One of these, a $145-\mathrm{kDa}$ protein has been localized to cold stable microtubules in neurons ${ }^{27}$. Periodic distribution of such proteins along neuritic microtubules might define regions which are relatively resistant to cold or $\mathrm{Ca}^{2+}$-induced tubulin depolymerization.

Differences in the rate of cell lysis induced by low micromolar concentrations of $\mathrm{H}_{2} \mathrm{O}_{2}$ seen between $\mathrm{PC}$ 12 cells in comparison with earlier studies of endothelial cells cannot be accounted for on the basis of differences in rates of catalase-dependent $\mathrm{H}_{2} \mathrm{O}_{2}$ consumption by the cells. It is interesting to note that in these experiments aminotriazole-inhibitable $\mathrm{H}_{2} \mathrm{O}_{2}$
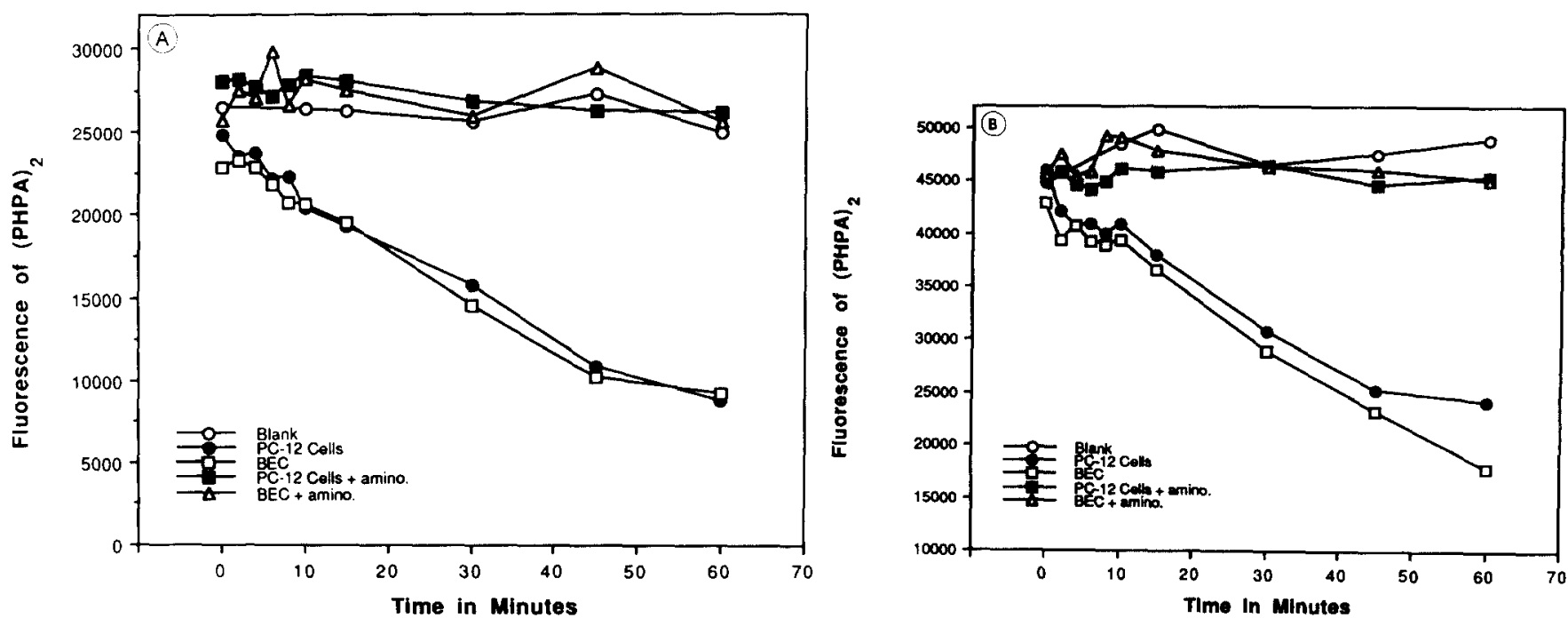

Fig. 12. $\mathrm{H}_{2} \mathrm{O}_{2}$ consumption by adherent $\mathrm{PC} 12$ and endothelial cells. A: comparison of the consumption of a $100 \mu \mathrm{M}$ bolus of $\mathrm{H}_{2} \mathrm{O}_{2}$ by adherent PC 12 and endothelial cells (amino $=12 \mathrm{mM}$ 3-amino-1,2,4-triazole). Each data point represents the mean of $n=4-6$ separate determinations. $\mathrm{B}$ : comparison of the consumption of a $1 \mathrm{mM}$ bolus of $\mathrm{H}_{2} \mathrm{O}_{2}$ by adherent $\mathrm{PC} 12$ and endothelial cells (amino = 12 mM 3-amino-1,2,4-triazole) Each data point represents the mean of $n=4-6$ separate determinations. 
consumption accounted for essentially all $\mathrm{H}_{2} \mathrm{O}_{2}$ consumption by both cell types at high and low $\mathrm{H}_{2} \mathrm{O}_{2}$ concentrations. In previous work we found that endothelial cells are quite resistant to $\mathrm{H}_{2} \mathrm{O}_{2}$-mediated disruption of $\left[\mathrm{Ca}^{2+}\right]_{i}$ homeostasis, requiring millimolar concentrations of the oxidant to induce significant elevation of $\left[\mathrm{Ca}^{2+}\right]_{i}^{10}$. If our modelling of the $\mathrm{H}_{2} \mathrm{O}_{2}$-mediated PC 12 injury with ionomycin is correct, the differentiated PC 12 cells may be quite vulnerable to oxidant-mediated disruption of $\left[\mathrm{Ca}^{2+}\right]_{\mathrm{i}}$ homeostasis and this difference may account for the more rapid kinetics of cell lysis seen with these cells. This would also be consistent with the important role elevation of $\left[\mathrm{Ca}^{2+}\right]_{i}$ is thought to play in the action of other neurotoxins ${ }^{18}$. A recent study of $\mathrm{H}_{2} \mathrm{O}_{2}$-mediated injury to undifferentiated PC 12 cells demonstrated that low micromolar concentrations of $\mathrm{H}_{2} \mathrm{O}_{2}$ could increase $\left[\mathrm{Ca}^{2+}\right]_{j}$ in the cells ${ }^{7}$.

In summary, PC 12 cells differentiated to a neuronal phenotype with NGF treatment provide an excellent cellular model for examination of the toxic effects of oxidants on neurons. PC 12 neurites and particularly neuritic microtubules are early targets of $\mathrm{H}_{2} \mathrm{O}_{2}$ injury, and this injury appears to be $\mathrm{Ca}^{2+}$-dependent.

Acknowledgements. The authors wish to thank Sue Stuth for her expert assistance with the electron microscopy and Stacy Wilkin and Jane Rheault for their assistance with preparation of the manuscript. Supported by a grant from Eli Lilly and Co., Indianapolis, IN and also in part by a Department of Veterans Affairs Merit Review (D.B.H., G.M.O.).

\section{REFERENCES}

1 Black, M.M. and Keyser, P., Acetylation of a-tubulin in cultured neurons and the induction of $\alpha$-tubulin acetylation in PC 12 cells by treatment with nerve growth factor, $J$. Neurosci., 7 (1987) 1833-1842.

2 Braughler, J.M. and Hall, E.D., Central nervous system trauma and stroke. 1. Biochemical considerations for oxygen radical formation and lipid peroxidation, Free Rad. Biol. Med., 6 (1989) 289-301.

3 Cambray-Deakin, M.A., Cytoskeleton of the growing axon in the neuronal cytoskeleton, R.D. Burgoyne (Ed.), Wiley-Liss, New York, 1991, pp. 233-255.

4 Cambray-Deakin, M.A. and Burgoyne, R.D., Postranslational modifications of alpha-tubulin: acetylated and detyrosinated forms in axons of rat cerebellum, J. Cell Biol, 104 (1987) 1569-1574.

5 Greene, L.A. and Tischler, A.S., Establishment of a nor-adrenergic clonal line of rat adrenal pehochromocytoma cells which respond to nerve growth factor, Proc. Natl. Acad. Sci. USA, 73 (1976) 2424-2428.

6 Hall, E.D. and Braughler, J.M., Central nervous system trauma and stroke. II. Physiological and pharmacological evidence for involvement of oxygen radicals and lipid peroxidation Free Rad. Biol. Med., 6 (1989) 303-313.

7 Halleck, M.M., Richburg, J.H. and Kauffman, F.C., Reversible and irreversible oxidant injury to PC 12 cells by hydrogen peroxide, Free Rad. Biol. Med., 12 (1992) 137-144.
8 Halliwell, B., Oxidants and the central nervous system: some fundamental questions. Is oxidant damage relevant to Parkinson's disease, Alzheimer's disease, traumatic injury or stroke?, Acta Neurol. Scand., 126 (1989) 23-33.

9 Hinshaw, D.B., Armstrong, B.C., Burger, J.M., Beals, T.F. and Hyslop, P.A., ATP and microfilaments in cellular oxidant injury, Am. J. Pathol, 132 (1988) 479-488.

10 Hinshaw, D.B., Burger, J.M., Armstrong, B.C. and Hyslop, P.A., Mechanism of endothelial cell shape change in oxidant injury, $J$. Surg. Res., 46 (1989) 339-349.

11 Hinshaw, D.B., Burger, J.M., Beals, T.F., Armstrong, B.C. and Hyslop, P.A., Actin polymerization in cellular oxidant injury, Arch. Biochem. Biophys., 288 (1991) 311-316.

12 Hinshaw, D.B., Burger, J.M., Omann, G.M. and Hyslop, P.A., $\mathrm{H}_{2} \mathrm{O}_{2}$ can exert toxic effects on endothelial cells independent of ATP synthetic pathways, Free Rad. Biol. Med., 9 (1990) 108A.

13 Hinshaw, D.B., Sklar, L., Bohl, B., Schraufstatter, I., Hyslop, P., Rossi, M., Spragg, R. and Cochrane, C.G., Cytoskeletal and morphological impact of cellular oxidant injury, Am. J. Pathol., 123 (1986) 454-464.

14 Hyslop, P.A., Hinshaw, D.B., Schraufstatter, I.U., Spragg, R.G., Sklar, L.A. and Cochrane, C.G., Intracellular calcium homeostasis during hydrogen peroxide injury to cultured $\mathrm{P}_{388 \mathrm{D}_{1}}$ cells, $J$. Cell. Physiol., 129 (1986) 356-366.

15 Hyslop, P.A. and Sklar, L.A., A quantitative fluorimetric assay for the determination of oxidant production by polymorphonuclear leukocytes: its use in the simultaneous fluorimetric assay of cellular activation processes, Anal. Biochem., 141 (1984) 280-286.

16 Jesberger, J.A. and Richardson, J.S., Oxygen free radicals and brain dysfunction, Int. J. Neurosci., 57 (1991) 1-17.

17 Jewell, S.A., Bellomo, G., Thor, H., Orrenius, S. and Smith, M.T., Bleb formation in hepatocytes during drug metabolism is caused by disturbances in thiol and calcium ion homeostasis, Science, 217 (1982) 1257-1259.

18 Komulainen, H. and Bondy, S.C., Increased free intracellular $\mathrm{Ca}^{2+}$ by toxic agents; an index of potential neurotoxicity?, Trends Pharmacol. Sci., 9 (1988) 154-156.

19 Kontos, H.A., Oxygen radicals in CNS damage, Chem. Biol. Interactions, 72 (1989) 229-255.

20 Kontos, H.A. and Wei, E.P., Superoxide production in experimental brain injury, J. Neurosurg., 64 (1986) 803-807.

21 Margolis, R.L., Rauch, C.T. and Job, D., Purification and assay of a $145-\mathrm{kDa}$ protein $\left(\mathrm{STOP}_{145}\right.$ ) with microtubule-stabilizing and motility behavior, Proc. Natl. Acad. Sci. USA, 83 (1986) 639-643.

22 Martin II, W.J., Neutrophils kill pulmonary endothelial cells by a hydrogen peroxide dependent pathway, Am. Rev. Resp. Dis., 130 (1984) 209-213.

23 Mirabelli, F., Salis, A., Marinoni, V., Finardi, G., Bellomo, G., Thor, H. and Orrenius, S., Menadione-induced bleb formation in hepatocytes is associated with the oxidation of thiol groups in actin, Arch. Biochem. Biophys., 264 (1988) 261-269.

24 Mirabelli, F., Salis, A., Perotti, M., Taddei, F., Bellomo, G. and Orrenius, S., Alterations of surface morphology caused by the metabolism of menadione in mammalian cells are associated with the oxidation of critical sulfhydryl groups in cytoskeletal proteins, Biochem. Pharmacol, 37 (1988) 3423-3427.

25 Mirabelli, F., Salis, A., Vairetti, M., Bellomo, G., Thor, H., and Orrenius, S., Cytoskeletal alterations in human platelets exposed to oxidative stress are mediated by oxidative and $\mathrm{Ca}^{2+}$-dependent mechanisms, Arch. Biochem. Biophys., 270 (1989) 478-488.

26 Okabe, S. and Hirokawa, N., Microtubule dynamics in nerve cells: analysis using micro injection of biotinylated tubulin into PC 12 cells, J. Cell Biol., 107 (1988) 651-664.

27 Pirollet, F., Rauch, C.T., Job, D. and Margolis, R.L., Monoclonal antibody to microtubule-associated STOP protein: affinity purification of neuronal STOP activity and comparison of antigen with activity in neuronal and non-neuronal cell extracts, Biochemistry, 28 (1989) 835-842.

28 Povlishock, J.T., The morphopathologic responses to experimental head injuries of varying severity. In D.P. Becker and J.T. 
Povlishock (Eds.), Central Nervous System Trauma Status Report, National Institute of Neurological and Communicative Disorders and Stroke, National Institutes of Health, 1985, pp. 443-452.

29 Rickard, J. and Kreis, T., Binding of pp170 to microtubules is regulated by phosphorylation, J. Biol. Chem., 266 (1991) $17597-$ 17605 .
30 Schraufstatter, I.U., Hyslop, P.A., Jackson, J.H. and Cochrane, C.G., Oxidant-induced DNA damage of target cells, J. Clin. Invest., 82 (1988) 1040-1050.

31 Wei, E.P. and Kontos, H.A., Oxygen radicals in cerebral ischemia, Physiologist, 30 (1987) 122. 